\title{
Pricing and Hedging \\ Mandatory Convertible Bonds
}

\author{
Manuel Ammann
}

Ralf Seiz

Working Paper Series in Finance

Paper No. 16 


\title{
Pricing and Hedging \\ Mandatory Convertible Bonds
}

\author{
Manuel Ammann and Ralf Seiz*
}

December 2004 (revised January 2006)

\begin{abstract}
This article examines the pricing and hedging of mandatory convertible bonds on the US market using daily market prices for a period of 498 trading days resulting in a sample of over 14,600 daily price observations. We explore the pricing and hedging performance based on a simple contingent claims model. On average, the pricing errors are lower than those found for standard convertible bonds. An analysis of the hedging performance of the model indicates that the model is useful for hedging as, on average, the hedging errors observed are relatively small and mostly unsystematic.
\end{abstract}

Keywords: mandatory convertibles, hybrid securities, convertible bonds JEL classification: G12, G13, G15

\footnotetext{
* Manuel Ammann is professor of finance and Ralf Seiz is Ph.D. candidate and research assistant at the University of St.Gallen. Address: Swiss Institute of Banking and Finance, University of St. Gallen, Rosenbergstrasse 52, 9000 St.Gallen, Switzerland. Tel: +4171-224-7090, Fax +4171-224-7088, Email: manuel.ammann@unisg.ch, ralf.seiz@unisg.ch. We would like to thank Bernd Brommundt, Michael Genser, Stephan M. Kessler, Axel Kind, Michael Verhofen, Rico von Wyss, the editor Stephen Figlewski, and an anonymous referee for their helpful comments. Financial support by the Swiss National Science Foundation (SNF) is gratefully acknowledged.
} 


\section{Introduction}

We study the pricing and hedging of mandatory convertible bonds on the secondary market. So far, no such investigation has been conducted. The pricing of 40 mandatory convertibles is analyzed between May 2002 and April 2004 with a total of 498 trading days yielding a sample of 14,612 daily price observations. These securities were issued in the United States between October 2000 and July 2003 and mature between May 2004 and November 2006. We examine the US market for mandatory convertibles because of the availability of accurate daily market prices, its large size compared to other markets and the liquidity of many of its issues.

Mandatory convertibles are equity-linked hybrid securities and can be thought of as yieldenhanced equity. Mandatory convertibles pay higher dividends than common stock for a number of years and then mandatorily convert to common stock on a pre-specified date. These securities are the most equity-like of all convertible securities and, unlike normal convertibles, they provide little downside protection because mandatory convertibles usually have no fixed terminal value. Instead, the security will mandatorily convert into a variable number of shares at maturity. Mandatory convertibles have become popular in recent times: Chemmanur and Nandy [2003] report about \$20 billion issued in 2001 implying a market share of approximately $18 \%$ of the convertible bond market.

Despite the large size of international and especially US mandatory convertible markets, very little research on the pricing of mandatory convertibles has been undertaken. Previous work includes Arzac [1997], who discusses the rationale for mandatory convertibles from 
the point of view of issuers as well as investors. He notes that mandatory convertibles allow highly leveraged (or temporarily troubled) companies to restructure their balance sheet by helping to control for the "asymmetric information" problem. Furthermore, he describes the main features and a straightforward valuation method. Chen at al. [1999] provide an analysis of one (Masco Tech) mandatory convertible for a time period of one year. They use the same valuation method as Arzac [1997] and show that mandatory convertibles are not very sensitive to changes in volatility, risk-free interest rate, and credit spread.

There are also a few articles dealing with the rationale of and the stock market reactions to issuing mandatory convertibles: Huckins [1999] investigates the characteristics of firms issuing such bonds and the announcement effect on stock prices. She finds that companies that issue mandatory convertibles tend to be highly leveraged. She also finds a neutral response of the stock market to announcements and issues of mandatory convertibles and attributes this effect to the mitigation of adverse selection costs compared to equity issues. Chemmanur and Nandy [2003] provide a theoretical model explaining the announcement effect. Furthermore, they also show that, in equilibrium, the company issues straight debt, ordinary convertibles, or equity if the extent of asymmetric information is large, but the probability of being in financial distress is relatively small. It issues mandatory convertibles if the problem of asymmetric information is small but the probability of financial distress is high. Hegde and Krishnan [2003] test predictions of agency and asymmetric information theories to explain why some firms prefer to use mandatory convertibles as opposed to ordinary convertible securities. They find that the stock market 
reacts less negatively to a mandatory convertible issue than to an ordinary convertible issue.

The paper is organized as follows: In Section 2, we describe the structure and characteristics of a typical mandatory convertible and describe the pricing model. Section 3 gives an overview of the data set and the methodology for the empirical analysis. The empirical results of the pricing study are reported in Section 4. Section 5 examines the hedging performance and Section 6 concludes.

\section{Pricing Model}

\subsection{Description of Mandatory Convertible Bonds}

In our study, we analyze the most common mandatory convertible bond structure. Mandatories pay a coupon, are subject to the full downside risk of the stock, and participate (partially) in the upside potential of the stock. Typically, there is a flat payoff zone between a lower strike price and an upper strike price, where the payoff at maturity is fixed. These securities, referred to by various acronyms such as PIES, DECS, ACES, PRIDES, etc., therefore have characteristics of both common and preferred stock. For simplicity, we call the payoff structure described in this section simply "mandatory convertible" and use this term interchangeably with the acronyms given to these securities by the issuing investment banks. 
Typically, a mandatory convertible pays a coupon in percent of the par value that is 5 to 7 percentage points higher than the underlying common stock's dividend yield. The annual coupon is usually paid quarterly. The securities are usually issued with a maturity of 3 to 5 years. At maturity, they are mandatorily converted into common stock. Often, they are call-protected for most or all of their life. A unique characteristic of mandatory convertibles is that the conversion ratio depends on the price of the underlying stock. The payoff $\left(V_{T}\right)$ at maturity $(T)$ is given by:

$$
V_{T}=\left\{\begin{array}{cc}
S_{T} \cdot R_{U} & \text { if } S_{T} \geq X_{U} \\
S_{T} \cdot R_{B}=P & \text { if } X_{L}<S_{T}<X_{U} \\
S_{T} \cdot R_{L} & \text { if } S_{T} \leq X_{L}
\end{array} .\right.
$$

At maturity, if the stock price has fallen below a lower strike price $\left(X_{L}\right)$, investors usually receive a fixed lower ratio $\left(R_{L}\right)$ of shares. If the stock price is between a lower $\left(X_{L}\right)$ and an upper strike price $\left(X_{U}\right)$, then investors receive stock worth as much as the par value $(P)$, i.e., the stock price $\left(S_{T}\right)$ is multiplied by the variable ratio $\left(R_{B}\right)$ between the lower and the upper strike price. This variable ratio $\left(R_{B}\right)$ is determined by dividing the par value $(P)$ by the stock price at expiration $\left(S_{T}\right)$. If the stock price is above the upper strike $\left(X_{U}\right)$, the investor receives a fixed upper ratio $\left(R_{U}\right)$ of shares. Exhibit 1 illustrates the payoff profile of a mandatory convertible at maturity.

\section{[Exhibit 1]}


Note that the lower strike price multiplied by the lower ratio is equal to the upper strike price multiplied by the upper ratio and both are equal to the par value $(P)$ of the mandatory convertible $\left(X_{L} \cdot R_{L}=X_{U} \cdot R_{U}=P\right)$. The conversion ratio at the lower strike price is always higher than the ratio at the upper strike price. Therefore, if the stock increases from the lower strike price, an investor's participation is delayed until the upper strike price is reached. Above the upper strike price, the investor participates at a reduced rate equal to the upper conversion ratio, which is less than 1 (the reverse is true for $S_{T}<X_{L}$ ).

\subsection{The Pricing Model}

Arzac [1997] presents a simple valuation method, decomposing the securities into three basic components that are each readily valued individually: (1) the current value of the underlying common stock; (2) the fixed-income cash flow (present value of the coupon payments minus the present value of the dividend payments of the common stock); and (3) the stock options embedded in the security $\left(R_{U}\right.$ calls with strike price $X_{U}$ minus $R_{L}$ calls with strike price $X_{L}$ ). Chen at al. [1999] use the same valuation method as Arzac [1997]. ${ }^{1}$ Alternatively, the following equivalent decomposition can also be used: (1) a fixed income component with principle $P$ paying the coupons $I$; (2) minus $R_{L}$ puts with strike price $X_{L}$; (3) plus $R_{U}$ calls with strike price $X_{U}$. For our analysis we use the second decomposition ${ }^{2}$.

The fair value or the (theoretical) model price of the mandatory convertible is the price at which it could be replicated theoretically. In the secondary market, the fair value of the mandatory convertible at time $t\left(V_{t}\right)$ consists of the following components ${ }^{3}$ : 
+ value of a call with upper strike price multiplied by the upper ratio $\left(c_{t, U} \cdot R_{U}\right)$,

- value of a put with lower strike price multiplied by the lower ratio $\left(p_{t, L} \cdot R_{L}\right)$,

+ present value of the (risk-free) par value $e^{4}\left(P V_{t}(P)\right)$,

+ present value of the (risky) coupon payments $\left(P V_{t}(I)\right)$.

Therefore, on valuation date $t$, the mandatory convertible has a value of

$$
V_{t}=c_{t, U} \cdot R_{U}-p_{t, L} \cdot R_{L}+P V_{t}(P)+P V_{t}(I)
$$

The present value of the (riskless) par value is defined as

$$
P V_{t}(P)=P \cdot e^{-\left(r_{t, \Delta T}\right) \cdot \Delta T}
$$

and the present value of the (risky) coupon payment is defined as

$$
P V_{t}(I)=\sum_{j=1}^{m} I \cdot e^{-\left(r_{t, j-t}+c s_{t}\right) \cdot\left(t_{j}-t\right)}
$$

The notation is as follows:

$P=$ par value of the mandatory convertible

$t=$ time of valuation

$T=$ maturity of the mandatory convertible

$\Delta T=T-t=$ the time in years until maturity of the mandatory convertible

$V_{t}=$ value of the mandatory convertible at time $t$

$R_{U}=$ upper ratio 
$R_{L}=$ lower ratio

$c_{t, U}=$ price of a European call option with strike price $X_{U}$ at time $t$

$p_{t, L}=$ price of a European put option with strike price $X_{L}$ at time $t$

$P V_{t}(I)=$ present value of coupon payment of the mandatory convertible at time $t$

$P V_{t}(P)=$ present value of par value at time $t$

$I=$ coupon for a given bond

$t_{j}=$ date of the $j$-th coupon payment, $j=1,2, \ldots, m$ with $t \leq t_{j} \leq T$

$r_{t, t j-t}=$ continuously compounded riskless interest rate at time $t$ for the period $t_{j}-t$

$r_{t, \Delta T}=$ continuously compounded riskless interest rate at time $t$ for the period $\Delta T$

$C S_{t}=$ credit spread of the mandatory convertible at time $t$

The Black and Scholes [1973] and Merton [1973] model can be applied to these options only if it can be assured that early exercise is never optimal. Otherwise, numerical techniques such as binomial trees would have to be used. However, if the coupon payments exceed the (expected) dividend payments (this is the case in our sample) on the common stock, then early exercise is never optimal. It is therefore viable to use the Black-ScholesMerton option pricing formula for European options on shares paying a known dividend yield. The dividend yield at time $t$ is expressed as a continuously compounded annual rate $q_{t}$. The value for a call $c_{t, k}$ and a put $p_{t, k}$ at time $t$ for an option with strike price $X_{k}$ is given by:

$$
\begin{aligned}
& c_{t, k}=S_{t} \cdot e^{-q_{t} \cdot \Delta T} \cdot \phi(d)-X_{k} \cdot e^{-r_{t, \Delta T} \cdot \Delta T} \cdot \phi\left(d-\sigma_{t} \cdot \sqrt{\Delta T}\right) \\
& p_{t, k}=X_{k} \cdot e^{-r_{t, \Delta T} \cdot \Delta T} \cdot \phi\left(-d+\sigma_{t} \cdot \sqrt{\Delta T}\right)-S_{t} \cdot e^{-q_{t} \cdot \Delta T} \cdot \phi(-d) \\
& \text { with } d=\left\{\ln \left(\frac{S_{t}}{X_{k}}\right)+\left(r_{t, \Delta T}-q_{t}+\frac{\sigma_{t}^{2}}{2}\right) \cdot \Delta T\right\} / \sigma_{t} \cdot \sqrt{\Delta T},
\end{aligned}
$$


where $S_{t}$ is the market price of the underlying asset at time $t, q_{t}$ the continuously compounded annual dividend yield at time $t, \sigma_{t}$ the volatility for the underlying asset at time $t$, and $\phi($.$) is the standard normal cumulative distribution function.$

In our model, mandatory convertible prices depend on several parameters, namely credit spreads, stock price volatilities, risk-free interest rates and dividend yields. The price impact of those parameters varies greatly. Because mandatory convertibles are essentially yield-enhanced common stock, they are very sensitive to a change in the underlying stock (see Section 5 for an analysis of the hedging performance). Dividend estimations can be critical, because future dividends of the underlying stock are uncertain and the coupon payments of the mandatory convertible are fixed. Due to the offsetting nature of the embedded option spread, a change in volatility has only a minor effect on the mandatory convertible value (see Section 4 for a detailed analysis). Therefore, the impact of the volatility model on model prices is limited. A change in credit spread affects only the present value of the coupon payments and therefore also has a limited impact on prices. Finally, because mandatory convertibles are akin to stock rather than debt, they are not very sensitive to changes in interest rates.

\section{Data Set and Methodology}

Mandatory convertible bonds are not always issued by corporate debtors. There are also "synthetic" bonds created by investment banks in response to investor demand without the corporate's involvement. In those cases, the counterparty is the bank, not the corporate 
debtor. In this study, however, the counterparties of all mandatory convertibles analyzed are corporate debtors.

Our sample covers 46 mandatory convertible bonds. We exclude 4 callable $^{5}$ securities and 2 bonds where companies have repurchased a large fraction of the outstanding securities. Therefore, we examine market prices of 40 US mandatory convertibles from May 28, 2002 to April 22, 2004 (representing 498 trading days) issued in the US between October 2000 and July 2003 and maturing between May 2004 and November 2006. The sample contains 14,612 data points. Mandatory convertible prices and stock prices were provided by Reuters and Datastream, respectively. For the riskless interest rate, we use the interpolated US zero curve yield calculated from swap rates for the respective maturity, provided by Datastream. Apart from directly observable input parameters, such as stock prices, prices of mandatory convertibles and interest rates, the pricing model requires input parameters that have to be estimated and thus are a source of estimation error. These variables include dividend yields, credit spreads and volatilities. Information on current dividend yields at time $t$ of the underlying common stock was provided by Datastream. For an appropriate default-adjusted interest rate $\left(r_{t, \Delta t}+c s_{t}\right)$, we use the credit ratings provided by Moody's and use the respective Moody's median bond spread data that provide average credit spreads $\left(C s_{t}\right)$ for time $t$. Although a change in credit spreads can often have significant effects on the pricing of traditional convertible bonds, its impact here is limited because credit spreads affect only the present value of the coupon payments. 
Because of the offsetting nature of the embedded option spread in mandatory convertibles, a change in volatility of the underlying asset has a minor effect on pricing. A popular approach to determine volatilities is the implied volatility concept. However, there is no liquid options data available for many of the firms analyzed in this study. Furthermore, liquid options tend to have shorter maturities than mandatory convertibles. Consequently, we estimate volatilities on a historical basis. The relevant volatility is calculated as the standard deviation of the returns of the last four years. Exhibit 6 in Section 4 shows that the results are robust with respect to this estimation window.

Most mandatory convertibles (39 out of 40) are American-style, that is, they allow exercise prior to maturity (i.e., settlement with the upper conversion ratio). However, in our sample, the coupon payments exceed the (expected) dividend payments on the common stock; early exercise is therefore never optimal. As a consequence, the early exercise feature does not have a price impact and therefore the valuation as a European-style security is justified. Another feature of some mandatory convertibles is that the "settlement price" used to determine the number of shares (conversion ratio) to be received for each mandatory convertible is the average closing price during a (generally small) number of pre-specified trading days immediately prior to maturity. This feature is similar to Asian options, where the value depends on the value of the asset not at expiration, but rather on the average value of a specified time period. The effect of averaging is to reduce the volatility of the option. When the averaging period is large in relation to the maturity of the option, the values of Asian options are significantly lower than those of the corresponding European options. In the case of mandatory convertibles, the averaging effect is small because the averaging periods are very short, and it is therefore neglected. 
Exhibit 2 provides the characteristics of the mandatory convertibles such as maturity, annual coupon, par value, upper ratio, lower ratio, upper and lower strike price. The securities mature between May 18, 2004 and November 16, 2006. All bonds pay quarterly coupons. The average annual coupon rate of the face value is $7.38 \%$. Exhibit 3 shows further average characteristics of our sample. The average time to maturity is about two years (average maturities over all data points), the average four-year historical volatility is $43 \%$, the average dividend yield of the underlying shares is $2.0 \%$, the average credit spread is 203 bps and the average moneyness ${ }^{6}$ is 1.02 (i.e., the average security is slightly 'in-themoney', i.e., the stock price is slightly above the upper strike price).

\section{[Exhibit 2]}

\section{[Exhibit 3]}

For each of the mandatory convertibles, our database provides daily price quotes $\left(V_{l, t}^{\text {market }}, l\right.$ $=1,2, \ldots, L ; t=1,2, \ldots, N_{l}$ where $N_{l} \leq 498$ denotes the number of records for the $l$-th bond and $L=40)$. To look at the relative price differences between market prices $\left(V_{l, t}^{\text {market }}\right)$ and model prices $\left(V_{l, t}^{\text {model }}\right)$, pricing errors $\left(E_{l, t}\right)$ at time $t$ in percent for a mandatory convertible bond $l$ are defined as:

$$
E_{l, t}=\frac{V_{l, t}^{\text {market }}-V_{l, t}^{\text {model }}}{V_{l, t}^{\text {model }}} .
$$


The model price $\left(V_{l, t}^{\text {model }}\right)$ of the mandatory convertible $l$ is obtained using Equation (2) at time $t$. For each mandatory convertible, we calculate the mean pricing error (arithmetic mean) of each security, defined as:

$$
E_{l}=\frac{1}{N_{l}} \sum_{t=1}^{N_{l}} E_{l, t}
$$

If the pricing errors in Equation (7) are positive, model prices tend to underestimate market prices and if they are negative, model prices tend to overestimate market prices.

Furthermore, for each mandatory convertible bond we calculate the root mean squared error (RMSE), defined as:

$$
\operatorname{RMSE}_{l}=\sqrt{\frac{1}{N_{l}} \sum_{t=1}^{N_{l}}\left(E_{l, t}\right)^{2}}
$$

\section{The Pricing of Mandatory Convertible Bonds}

\subsection{Overview}

The observed mandatory convertible prices on the US market are compared with theoretical prices obtained by the pricing model proposed in Section 2. Exhibit 4 shows an overview of pricing errors for all securities in the sample. The table provides the mean percentage pricing errors $E_{l}$, the root mean squared error $\left(\mathrm{RMSE}_{l}\right)$, the mean absolute error 
$\left(\mathrm{MAE}_{l}\right)$ and the standard deviation $\left(\sigma_{E, l}\right)$ of the pricing errors for each issue $l$. A negative value of the mean pricing error indicates an observed underpricing, i.e., the observed market price is below the theoretical value. In other words, the pricing model overprices the market. The mean over all mandatory convertibles in Exhibit 4 is defined as the average parameter of all 40 securities (e.g., the equally-weighted mean of the mean pricing error for each bond), whereas the results for the mean over all data points are calculated over the entire sample of data points, weighting each of the 14,612 data points equally.

Exhibit 4 shows the results of the pricing study. The mean RMSE is $3.58 \%$, the mean standard deviation $2.34 \%$. On average, the mandatory convertibles are slightly overpriced by $0.27 \%$ (i.e., the pricing model underestimates market prices). Although not negligible, the pricing errors are smaller than those reported in similar studies on standard U.S. convertible bonds. ${ }^{7}$ Further below, we will analyze these results in two respects: first, we explore the possible driving factors of the pricing errors and, second (in Section 5), we analyze the hedging performance of the valuation model.

\section{[Exhibit 4]}

Exhibit 5 shows the frequency distribution of the pricing errors for the whole sample of 14,612 data points. $42 \%$ of the pricing errors are positive; i.e., the market price is above the model price. The vast majority of values for $E_{l, t}$ are concentrated around zero, whereas the distribution has a mean of $0.33 \%$ and a median of $-0.65 \%$ with a standard deviation of $4.45 \%$. 


\section{[Exhibit 5]}

In Exhibit 6 pricing errors are shown for a changing rolling volatility estimation window ranging from 0.25 to 5 years. The pricing error distributions are very similar and indicate that the results are robust with respect to the changing volatility window used in the analysis. Tests for differences in the mean show that mean pricing errors are not statistically different from each other.

\section{[Exhibit 6]}

\subsection{Analysis of Pricing Errors}

This sub-section explores the driving factors for the pricing errors. First, we show a breakdown of the pricing error by moneyness of the option and second, pricing errors are regressed against the factors that enter the valuation model.

We define the moneyness $\left(M_{l, t}\right)$ of the mandatory convertible $l$ on day $t=1,2, \ldots, N_{l}$ by

$$
M_{l, t}=\left\{\begin{array}{cc}
\frac{S_{l, t}}{X_{l, L}} & \text { if } S_{l, t}<X_{l, L} \\
1 & \text { if } X_{l, L} \leq S_{l, t} \leq X_{l, L} \\
\frac{S_{l, t}}{X_{l, U}} & \text { if } S_{l, t}>X_{l, U}
\end{array}\right.
$$


The univariate relationship between the moneyness $\left(M_{l, t}\right)$ and the pricing errors $\left(E_{l, t}\right)$ is illustrated in Exhibit 7 and Exhibit 8. The mean pricing error for at-the-money $\left(M_{l, t}=1\right.$, i.e., the current stock price is between the lower and the upper strike price) mandatory convertibles is slightly below zero $(-0.61 \%)$. If the securities are out-of-the-money ( $M_{l, t}<1$, i.e., the current stock price is below the lower strike price), mean pricing errors tend to be positive $(1.22 \%$ and $4.25 \%)$ and model prices underestimate market values. On the contrary, if mandatory convertibles move in-the-money $\left(M_{l, t}>1\right.$, i.e., the current stock price is above the upper strike price), the model prices tend to overestimate the market values (mean pricing errors of $-1.90 \%$ and $-0.87 \%$ ). RMSE and standard deviation of pricing errors decrease remarkably as the bonds move in-the-money.

The pricing formula in Equation (2) is mainly sensitive to the current stock price, the coupon payments, and the expected dividend payments if the mandatory convertible is 'deep out-of-the-money' or 'deep in-the-money'. The only uncertain cash flow is the expected dividend payment. If investors expected higher dividend yields in the future than the current yield (i.e., the model input), market prices would be lower than model prices (see Equation (2)). Thus, for 'deep in-the-money' securities (i.e., stock prices have risen in the past), investors perhaps expect higher dividend yields in the future. Reversely, the same argument could be made for mean market prices above mean model prices (positive mean pricing errors). Alternatively, the pricing error pattern might also be attributable to the smile effect ${ }^{8}$. 
The high RMSE and standard deviation for out-of-the-money bonds may be an indication that future dividends are more uncertain if the underlying common stock has performed poorly. The increased RMSE for deep-out-of-the-money bonds can perhaps also be attributed to a lack of liquidity for these bonds. However, the insight from such a univariate analysis is limited because of the relatively small sample size and the multicollinearity among the explanatory factors.

\section{[Exhibit 7]}

\section{[Exhibit 8]}

To analyze whether pricing errors are systematic with respect to the input parameters, they are jointly regressed against the dividend yield $(q)$, the annual coupon $(I)$, the moneyness $(M)$, the maturity $(\Delta T)$, the credit spread $(c s)$ and the volatility $(\sigma)$. The regression is specified as follows:

$$
E_{l, t}=\alpha_{0}+\alpha_{1} q_{l, t}+\alpha_{2} I_{l}+\alpha_{3} M_{l, t}+\alpha_{4} \Delta T_{l, t}+\alpha_{5} C S_{l, t}+\alpha_{6} \sigma_{l, t}+\varepsilon_{l, t}
$$

where $\alpha_{i} \in \mathbb{R}, i=0,1,2, \ldots, 6 ; l=1,2, \ldots, 40 ; t=1,2, \ldots, N_{l}$ where $N_{l} \leq 498$. Correlation analysis shows that the dividend yield, the coupon, the volatility and the credit spread are rather highly correlated. Due to these correlations, we run the regressions in Equation (10) excluding the highly correlated regressors. The estimated standard errors are 
adjusted for autocorrelation and heteroskedasticity according to Newey and West [1987]. They develop a variance-covariance estimator that is consistent in the presence of both heteroskedasticity and autocorrelation. The truncation lag parameter represents the number of autocorrelations used in evaluating the dynamics of the OLS residuals and is set following the suggestion of Newey and West [1987] ${ }^{9}$. The results of the regressions are given in Exhibit 9.

\section{[Exhibit 9]}

Regressions (1) to (6) in Exhibit 9 show the individual regressions for the six independent variables. In regression (1) the constant $\alpha_{0}$ is significantly negative and the coefficient $\alpha_{1}=0.706$ is significantly positive. The scaling of the parameter q (in \%) implies an increase of $0.706 \%$ of the pricing error (e.g. from $1 \%$ to $1.706 \%$ ) for an increase of the dividend yield of $1 \%$ (i.e., from $2 \%$ to $3 \%$ ). Therefore, pricing errors increase if dividend yields increase, indicating that market participants perhaps expect lower dividends for the future if dividends are high. The same argument holds for regression (2), where the pricing errors increase with the coupon payments (the coefficient of 0.871 implies that pricing errors increase by $0.871 \%$ for a coupon increase of $1 \%$ ) due to the large correlation between the coupon and the dividend yield (correlation coefficient of 0.8). Firms with higher dividend yields on their common stock issue mandatory convertibles with higher coupon payments. In our sample, the mean "income advantage" (coupon payments in percent minus dividend yield in percent) is about $5.4 \%$ for the whole sample with a small

standard deviation of $1.4 \%$. Therefore, firms with high dividends tend to issue mandatory convertibles with high coupons to achieve a sufficient level of income advantage for the 
bond. So, the dividend yield and coupon effect can be attributed to the same pricing error source. In regression (3), the moneyness coefficient is significantly negative, showing that pricing errors decrease if the securities move in-the-money. This analysis supports the findings above (Exhibit 7), where in-the-money or deep in-the-money securities had a strong stock price appreciation in the past and therefore dividend payments are perhaps expected to increase. Regression (4) shows a significantly negative maturity coefficient $\left(\alpha_{4}=-0.017\right)$, implying a pricing errors decrease for larger maturities (an increase of the maturity of one year results in a decrease of $1.7 \%$ of the pricing error). Because we use a continuously compounded dividend yield instead of discrete dividend payments in the valuation model, short maturities tend to overestimate the dividend payments (the overestimation increases if the period between last dividend payment date and the maturity increases). In regression (5), the coefficient for the credit spread is significantly negative. As we have explained in Section 2, the influence of the credit spread on mandatory convertible pricing is fairly small because, other than for traditional convertibles, only the coupon payments need to be discounted by the credit spread-adjusted interest rate. Due to the negative correlation between credit spreads and dividend yields, this result is an indication that the credit spread coefficient might have the same error source as the dividend yield coefficient. In our sample, mandatory convertibles with higher dividends tend to have better credit ratings and therefore lower credit spreads. Finally, regression (6) confirms the results of the previous section that the volatility is not a source of systematic pricing errors.

The multivariate regressions (7) to (10) in Exhibit 9 show that the coefficients remain similar and that the statistical significance does not change, confirming the results of the 
univariate analysis in regression (1) to (6). All coefficients, except $\alpha_{6}$ for the volatility, are significant at the $1 \%$-level. However, the full model in Equation (10) is not tested due to the multicollinearity among several factors. The coefficient $\left(\alpha_{1}\right)$ for dividend yields has an adj. $R^{2}$ of about $11 \%$, the coefficient $\left(\alpha_{4}\right)$ for maturity has an adj. $R^{2}$ of about $8 \%$, whereas, the four other parameters have an adj. $R^{2}$ of less than $5 \%$. These results indicate that dividends can explain pricing errors better than the other candidate parameters. The adj. $R^{2}$ can be further increased in regressions (7) to (10) by using non-correlated regressors, increasing the adj. $R^{2}$ substantially. Regression (10) has the highest adj. $R^{2}$ of about $23 \%$, combining the dividend yield, the moneyness and the maturity of the mandatory convertibles. 


\section{The Hedging of Mandatory Convertible Bonds}

In practice, hedging and understanding and managing the risk exposure of mandatory convertible bonds is just as relevant as pricing. Therefore, besides pricing, a second measure to asses a contingent claims model is its hedging performance. In this section we analyze how accurately our model predicts price changes in addition to price levels. In particular, we analyze whether the delta from the model gives a good indication of how much the market value of the bond's price, $V_{t}^{\text {market }}$, changes when the underlying stock price $S$ changes.

We use delta-hedging to insulate a mandatory convertible bond position from the effects of stochastic changes in the price of the underlying asset ${ }^{10}$. Delta is the partial derivative of the mandatory convertible bond model price $V_{t}^{\text {model }}$ with respect to a change in the price of the underlying stock $S$. The definition of delta $\delta_{t}$ at time $t$ is $^{11}$ :

$$
\begin{aligned}
& \delta_{t}=\frac{\partial V_{t}^{\text {model }}}{\partial S_{t}}=\frac{\partial c_{t, U}}{\partial S_{t}} \cdot R_{U}-\frac{\partial p_{t, L}}{\partial S_{t}} \cdot R_{L} \\
& =\left\{e^{-q_{t} \cdot \Delta T} \cdot \phi\left(d_{U}\right)\right\} \cdot R_{U}-\left\{e^{-q_{t} \cdot \Delta T}\left[\phi\left(d_{L}\right)-1\right]\right\} \cdot R_{L} \\
& \text { with } V_{t}^{\text {model }}=c_{t, U} \cdot R_{U}-p_{t, L} \cdot R_{L}+P \cdot e^{-\left(r_{t, \Delta T}\right) \cdot \Delta T}+\sum_{j=1}^{m} I \cdot e^{-\left(r_{t, t j-t}+c s_{t}\right) \cdot\left(t_{j}-t\right)} \\
& \text { and } d_{k}=\left\{\ln \left(\frac{S_{t}}{X_{k}}\right)+\left(r_{t, \Delta T}-q_{t}+\frac{\sigma_{t}^{2}}{2}\right) \cdot \Delta T\right\} / \sigma_{t} \cdot \sqrt{\Delta T}
\end{aligned}
$$

We examine the hedging performance by setting up delta-neutral positions. The position is assumed to be held for one trading day (later we extend the analysis with a rebalancing 
period of 5 trading days). Ignoring the holding period expected return on the position $\left(B_{t}-B_{t-1}=\Delta B_{t} \approx 0\right)$, which is very small for such a short holding period, we set up the following hedge position:

$$
\begin{aligned}
& \text { (1) } S_{t-1} \cdot \delta_{t-1}+B_{t-1}=V_{t-1}^{\text {market }}(\text { at time t-1) } \\
& \text { (2) } S_{t} \cdot \delta_{t-1}+B_{t}+\varepsilon_{t}^{\text {market }}=V_{t}^{\text {market }}(\text { at time } \mathrm{t}) \\
& \Rightarrow\left(S_{t}-S_{t-1}\right) \cdot \delta_{t-1}+\left(B_{t}-B_{t-1}\right)+\varepsilon_{t}^{\text {market }}=V_{t}^{\text {market }}-V_{t-1}^{\text {market }} \\
& \Leftrightarrow \underbrace{\left(\Delta S_{t}\right) \cdot \delta_{t-1}}_{\equiv \Delta H_{t}}+\underbrace{\left(\Delta B_{t}\right)}_{\approx 0}+\varepsilon_{t}^{\text {market }}=\Delta V_{t}^{\text {market }}
\end{aligned}
$$

The parameters at time $t$ are defined as following: $V_{t}^{\text {market }}$ is the market value of the bond's price, $\varepsilon_{t}^{\text {market }}$ is the hedging error in dollar terms, $B_{t}$ is the money market account at time $t$ and $\Delta H_{t} \equiv \Delta S_{t} \cdot \delta_{t-1}$ is the hedge position. The hedging error in dollar terms $\left(\varepsilon_{t}^{\text {market }} \approx \Delta V_{t}^{\text {market }}-\Delta H_{t}\right.$ ) is the difference between the bond's price change and the change in the hedge position. To compare the different mandatory convertible bonds in their hedge performance, we use the hedging error in percent $\hat{\varepsilon}_{t}^{\text {market }}$ of the market's bond price $V_{t}^{\text {market }}$ :

$$
\hat{\varepsilon}_{t}^{\text {market }} \approx \frac{\Delta V_{t}^{\text {market }}-\Delta H_{t}}{V_{t}^{\text {market }}}=\frac{\varepsilon_{t}^{\text {market }}}{V_{t}^{\text {market }}}
$$

Hedging performance is measured by mean percentage hedging error, root mean squared error (RMSE) and mean absolute error. Exhibit 10 presents the hedging overview for all securities. Overall, delta hedges based on the hedge of the market price position $\left(V_{t}^{\text {market }}\right)$ 
show a RMSE of about $1.14 \%$. The mean percentage hedging error is $-0.01 \%$ and not significantly different from zero. Furthermore, none of the mean percentage hedging errors of the individual securities is significantly different from zero.

\section{[Exhibit 10]}

Next, we analyze the following three issues: (1) we compare the actual market hedge shown above with a hypothetical delta hedge against the model $\left(V_{t}^{\text {model }}\right)$. Such a comparison is used to determine to what extent the RMSE is caused by the delta hedging methodology (because of the linear approximation of a non-linear relationship, simple delta hedging always generates hedging errors even if the valuation model is perfect) and to what extent it is caused by the model, either by systematic misspecification or by unsystematic noise. (2) We explore whether there are systematic driving factors of the hedging errors with respect to the input parameters of the pricing model. (3) We analyze the hedging errors with a rebalancing period of five instead of one trading days to determine the influence of the rebalancing period on the hedging errors.

The hypothetical hedge against the model is equal to the hedge against the market, except that we use $V_{t}^{\text {model }}$ instead of $V_{t}^{\text {market }}$ for our hedge position. The hedging error of a perfect model is $\varepsilon_{t}^{\text {model }}=\Delta V_{t}^{\text {model }}-\Delta H_{t}$ and the hedging error in percent of the model price at time $\mathrm{t}$ is

$$
\hat{\varepsilon}_{t}^{\text {model }} \approx \frac{\left(V_{t}^{\text {model }}-V_{t-1}^{\text {model }}\right)-\Delta H_{t}}{V_{t}^{\text {model }}}=\frac{\Delta V_{t}^{\text {model }}-\Delta H_{t}}{V_{t}^{\text {model }}}=\frac{\varepsilon_{t}^{\text {model }}}{V_{t}^{\text {model }}}
$$


Exhibit 11 presents the hedging results of the hedge against the model. Overall, delta hedges based on the hedge against the model show a RMSE of approximately $0.27 \%$. The mean percentage hedging error is $-0.01 \%$. The RMSE over all data points $\left(14^{\prime} 572\right)$ is $0.33 \%$ and the mean hedging error is $-0.02 \%$ and significantly different from zero. The negative mean hedging errors are caused by the delta hedging methodology because the mean daily return of all data points is positive $(+0.1 \%)$. On average, the positive jumps of the underlying stock prices result in a slightly overestimated hedge position $\Delta H_{t}$ and slightly negative hedging errors. For a rebalancing period of one trading day, the results of Exhibit 10 and Exhibit 11 indicate that the hedging errors of the hedge against the market (RMSE of $1.14 \%$ ) are caused either by systematic errors and/or by market noise, given that the hedging error of a perfect model is much smaller (RMSE of $0.27 \%$ ).

\section{[Exhibit 11]}

Therefore, we explore next whether there are any systematic driving factors of the hedging errors with respect to the input parameters of the pricing model or whether the hedging errors are only unsystematic. Exhibit 12 presents the hedging errors classified by the dividend yield, the coupon payments, the moneyness, the maturity and the credit spread. Exhibit 12 shows that the mean percentage hedging errors are slightly negative, but none is significantly different from zero. The negative mean errors can be attributed to the delta hedging methodology and the, on average, increasing stock prices, as seen above in the hedge against the model (Exhibit 11). Exhibit 12 does not show any obvious systematic hedging errors measured in terms of mean errors or standard deviations with respect to the input parameters. 


\section{[Exhibit 12]}

Exhibit 13 shows the overview of the hedging performance with a rebalancing period of five trading days for the hedges against the market and the model. Both the mean percentage hedging errors $(-0.23 \%$ of the market hedge and $-0.21 \%$ of the model hedge) and the root mean squared errors $3.14 \%$ of the market hedge and $3.08 \%$ of the model hedge) are almost equal ${ }^{12}$. The RMSE of $3.14 \%$ and $3.08 \%$ show that for longer rebalancing periods, the hedge against the market is almost equivalent to the hedge against the model, indicating that the hedging error is almost entirely caused by the delta hedging methodology and that the effect of the model error is negligible. It therefore seems that the hedging error observed when rebalancing took place daily is mostly unsystematic, possibly caused by market noise such as jumps between bid and ask prices. As the rebalancing period is extended, the effect of the market noise decreases while the effect of the hedging methodology increases. As a consequence, the hedging errors (RMSE) of the hedge against the market converge in size to the hedging errors of the hedge against the model.

Although systematic errors of factors not investigated cannot be excluded, the results above indicate that for a rebalancing period of one trading day, the difference of the hedging errors of the hedge against the market (RMSE of $1.14 \%$ ) and the hedging error of the hedge against the model (RMSE of $0.27 \%$ ) consists, to a substantial extent, of unsystematic market noise possibly attributable to limited market liquidity.

\section{[Exhibit 13]}




\section{Conclusions}

A relatively large proportion of convertible bonds are currently issued as mandatory convertible bonds. We perform the first empirical analysis of the pricing and hedging of mandatory convertible bonds on the US market. The analysis uses daily market prices for 40 bonds for a period of 498 trading days employing a sample of over 14,600 daily price observations. The simple pricing model used in the analysis produces lower pricing errors than observed in pricing studies of standard convertible bonds. The results are robust with respect to the method of volatility estimation. Furthermore, the hedging analysis shows that the model is useful for hedging. The hedging errors tend to be small and unsystematic.

\section{References}

Ammann, M., A. Kind and C. Wilde. "Simulation-Based Pricing of Convertible Bonds." Working Paper, University of St. Gallen and University Frankfurt, (2005).

Arzac, E.R. "PERCS, DECS, and other Mandatory Convertibles." Journal of Applied Corporate Finance, vol. 10, no. 1 (Spring), (1997), pp. 54-63.

Black, F., and M. Scholes. "The Pricing of Options and Corporate Liabilities." Journal of Political Economy, vol. 81 (1973), pp. 351-376.

Chemmanur, T. and D. Nandy. "Why Issue Mandatory Convertibles? Theory and Empirical Evidence." Working Paper, Boston College, Carroll School of Management, (2003).

Chen, A.H.Y., K.C. Chen, and S. Howell. "An Analysis of Dividend Enhanced Convertible Stocks." International Review of Economics and Finance, vol. 8 (1999), pp. 327-338.

Das, R. S. and R. K. Sundaram. "A Simple Model for Pricing Securities with Equity, Interest-Rate, and Default Risk." Working Paper, Santa Clara and New York University, (2004). 
Diebold, F. X. and R. S. Mariano. "Comparing Predictive Accuracy." Journal of Business \& Economic Statistics, vol. 13, no. 3 (July), (1995), pp. 253-263.

Figlewski, S. "Assessing the Incremental Value of Option Pricing Theory Relative to an Informationally Passive Benchmark." Journal of Derivatives, vol. 10, no. 3 (Fall), (2002), pp. 80-96.

Hegde S. and K. Krishnan. "Choice between Mandatory and Ordinary Convertible Securities: An Examination of Signaling and Agency Effects." Working Paper, University of Connecticut, Boston College, Carroll School of Management, (2003).

Huckins, N.W. "An Examination of Mandatorily Convertible Preferred Stock." The Financial Review, vol. 34, (1999), pp. 89-108.

King, R. "Convertible bond valuation: An empirical test." Journal of Financial Research, vol. 9, no. 1, (1986), pp. 53-69.

Merton, R.C. "Theory of Rational Option Pricing." Bell Journal of Economics and Management Science, vol. 4, no.1, (1973), pp. 141-183.

Newey, W.K. and K.D. West. "A simple positive definite Heteroskedasticity and Autocorrelation consistent Covariance Matrix." Econometrica, vol. 55, (1987), pp. 703708. 


\section{Exhibits}

\section{Exhibit 1}

Payoff of a mandatory convertible at maturity

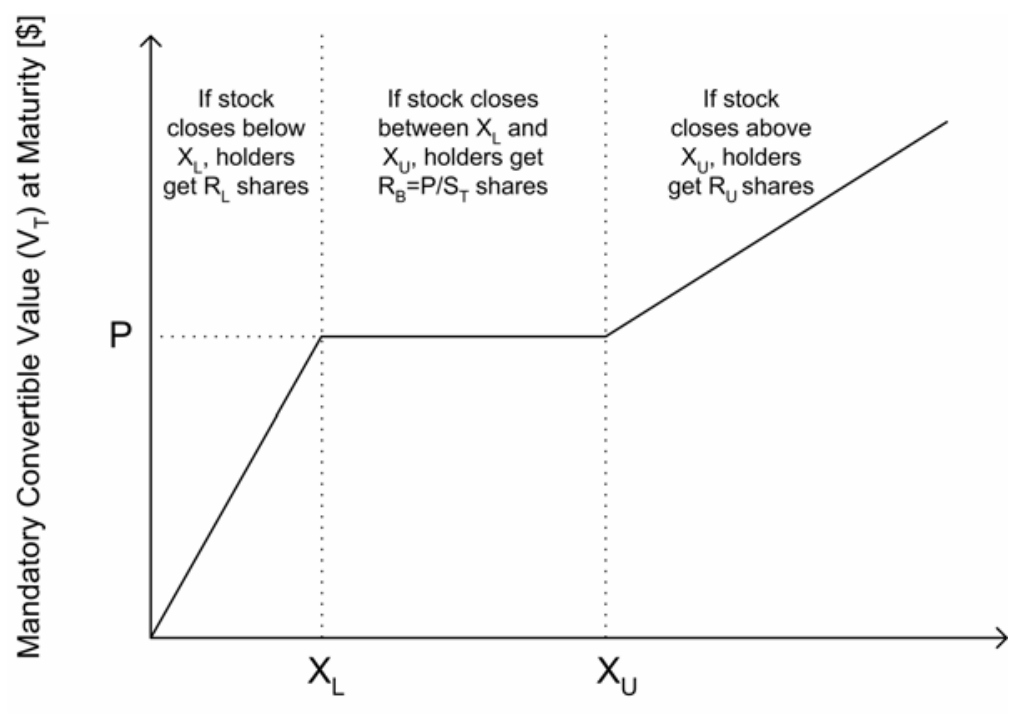

Stock Price $\left(\mathrm{S}_{\mathrm{T}}\right)$ at Maturity $[\$]$

The payoff profile of a mandatory convertible at maturity T. $\mathrm{X}_{\mathrm{L}}$ and $\mathrm{X}_{\mathrm{U}}$ denote the lower and upper strike price, $\mathrm{R}_{\mathrm{L}}$ and $\mathrm{R}_{\mathrm{U}}$ the lower and upper conversion ratio $\left(\mathrm{R}_{\mathrm{L}}>\mathrm{R}_{U}\right)$ and $\mathrm{P}$ denotes the par value of the security. 


\section{Exhibit 2}

Characteristics of mandatory convertible bonds

\begin{tabular}{|c|c|c|c|c|c|c|c|}
\hline Name of Issuer & Maturity & $\begin{array}{c}\text { Annual } \\
\text { Coupon } \\
(\%)\end{array}$ & $\begin{array}{c}\text { Par } \\
\text { Value (\$) }\end{array}$ & $\begin{array}{l}\text { Upper } \\
\text { Ratio }\end{array}$ & $\begin{array}{l}\text { Lower } \\
\text { Ratio }\end{array}$ & $\begin{array}{c}\text { Upper } \\
\text { Strike (\$) }\end{array}$ & $\begin{array}{c}\text { Lower } \\
\text { Strike (\$) }\end{array}$ \\
\hline AFFILIATED MANAGERS GROUP INC & 17.11.2004 & 6 & 25 & 0.45 & 0.51 & 56.05 & 48.73 \\
\hline ALLIED WASTE INDUSTRIES INC & 01.04 .2006 & 6.25 & 50 & 4.94 & 6.02 & 10.13 & 8.30 \\
\hline AMEREN CORP & 15.05 .2005 & 9.75 & 25 & 0.54 & 0.63 & 46.61 & 39.50 \\
\hline AMERICAN ELECTRIC POWER CO INC & 16.08 .2005 & 9.25 & 50 & 1.02 & 1.22 & 49.08 & 40.90 \\
\hline ANTHEM INSURANCE COMPANIES INC & 15.11 .2004 & 6 & 50 & 1.14 & 1.39 & 43.92 & 36.00 \\
\hline BAXTER INTERNATIONAL INC & 16.02.2006 & 7 & 50 & 1.40 & 1.74 & 35.69 & 28.78 \\
\hline CAPITAL ONE FINANCIAL CORP & 17.05 .2005 & 6.25 & 50 & 0.64 & 0.78 & 78.61 & 63.91 \\
\hline CENDANT CORP & 17.08 .2004 & 7.75 & 50 & 1.76 & 2.32 & 28.42 & 21.53 \\
\hline CENTURYTEL INC & 15.05 .2005 & 6.875 & 25 & 0.69 & 0.87 & 36.00 & 28.60 \\
\hline CHUBB CORP & 16.08 .2006 & 7 & 25 & 0.35 & 0.42 & 71.40 & 59.49 \\
\hline CITIZENS COMMUNICATIONS CO & 17.08 .2004 & 6.75 & 25 & 1.72 & 2.07 & 14.52 & 12.10 \\
\hline CONSTELLATION BRANDS INC & 01.09 .2006 & 5.75 & 25 & 0.73 & 0.89 & 34.16 & 28.00 \\
\hline CORNING INC & 16.08 .2005 & 7 & 100 & 50.81 & 62.50 & 1.97 & 1.60 \\
\hline DOMINION RESOURCES INC & 15.05 .2006 & 8.75 & 50 & 0.61 & 0.84 & 81.33 & 59.80 \\
\hline DOMINION RESOURCES INC & 16.11 .2004 & 9.5 & 50 & 0.82 & 0.98 & 61.20 & 51.00 \\
\hline DUKE ENERGY CORP & 18.05.2004 & 8.25 & 25 & 0.53 & 0.64 & 47.56 & 38.98 \\
\hline DUKE ENERGY CORP & 16.11 .2004 & 8 & 25 & 0.53 & 0.62 & 47.55 & 40.13 \\
\hline ELECTRONIC DATA SYSTEMS CORP & 17.08 .2004 & 7.625 & 50 & 0.70 & 0.84 & 71.47 & 59.31 \\
\hline EQUITY SECURITY TRUST II & 15.01 .2005 & 6.25 & 22.5 & 0.98 & 1.19 & 23.07 & 18.91 \\
\hline GABELLI ASSET MANAGEMENT INC & 17.02 .2005 & 6.95 & 25 & 0.54 & 0.63 & 46.50 & 39.40 \\
\hline HARTFORD FINANCIAL SERVICES GROUP INC, THE & 16.08 .2006 & 7 & 50 & 0.88 & 1.10 & 56.88 & 45.50 \\
\hline HARTFORD FINANCIAL SERVICES GROUP INC, THE & 16.11 .2006 & 6 & 50 & 0.87 & 1.06 & 57.65 & 47.25 \\
\hline HOUSEHOLD INTERNATIONAL INC & 15.02 .2006 & 8.875 & 25 & 0.97 & 1.17 & 25.68 & 21.40 \\
\hline IMC GLOBAL INC & 01.07 .2006 & 7.5 & 50 & 6.44 & 7.86 & 7.76 & 6.36 \\
\hline KEYSPAN CORP & 16.05.2005 & 8.75 & 50 & 1.18 & 1.42 & 42.36 & 35.30 \\
\hline MOTOROLA INC & 16.11.2004 & 7 & 50 & 2.37 & 2.89 & 21.08 & 17.28 \\
\hline ONEOK INC & 16.02.2006 & 8.5 & 25 & 1.21 & 1.45 & 20.63 & 17.19 \\
\hline PHELPS DODGE CORP & 15.08 .2005 & 6.75 & 100 & 2.08 & 2.50 & 48.00 & 40.00 \\
\hline PHOENIX COMPANIES INC, THE & 16.02.2006 & 7.25 & 25 & 2.83 & 3.46 & 8.82 & 7.23 \\
\hline PRUDENTIAL FINANCIAL CAPITAL TRUST I & 15.11 .2004 & 6.75 & 50 & 1.47 & 1.82 & 34.10 & 27.50 \\
\hline SEMPRA ENERGY & 17.05.2005 & 8.5 & 25 & 0.82 & 1.00 & 30.52 & 25.02 \\
\hline SOLECTRON CORP & 15.11.2004 & 7.25 & 25 & 2.16 & 2.55 & 11.58 & 9.81 \\
\hline SOUTHERN UNION CO & 16.08.2006 & 5.75 & 50 & 2.56 & 3.13 & 19.52 & 16.00 \\
\hline ST PAUL COMPANIES INC & 16.08.2005 & 9 & 50 & 1.72 & 2.07 & 29.04 & 24.20 \\
\hline TEMPLE-INLAND INC & 17.05.2005 & 7.5 & 50 & 0.79 & 0.96 & 63.44 & 52.00 \\
\hline TOYS R US INC & 16.08.2005 & 6.25 & 50 & 2.32 & 2.83 & 21.55 & 17.65 \\
\hline TXU CORP & 16.05 .2006 & 8.125 & 50 & 0.79 & 0.98 & 62.91 & 51.15 \\
\hline UNITED STATES STEEL CORP & 15.06.2006 & 7 & 50 & 3.19 & 3.83 & 15.66 & 13.05 \\
\hline UNUMPROVIDENT CORP & 15.05.2006 & 8.25 & 25 & 1.88 & 2.30 & 13.27 & 10.88 \\
\hline XEROX CORP & 01.07 .2006 & 6.25 & 100 & 8.13 & 9.76 & 12.30 & 10.25 \\
\hline
\end{tabular}

This exhibit provides the basic characteristics of the mandatory convertibles in our sample. Maturity is the due date of the security. The annual coupon is the percentage of the par value paid per year. The par value is the lower strike multiplied by the lower ratio or the upper strike multiplied by the upper ratio. The upper ratio and the lower ratio are the conversion ratios that specify the number of shares the mandatory convertible is converted into depending on the final stock price. The upper and lower strike prices determine the offsetting option spread and the characteristic payoff profile of the mandatory convertibles. 


\section{Exhibit 3}

Overview of average input parameters for the pricing model

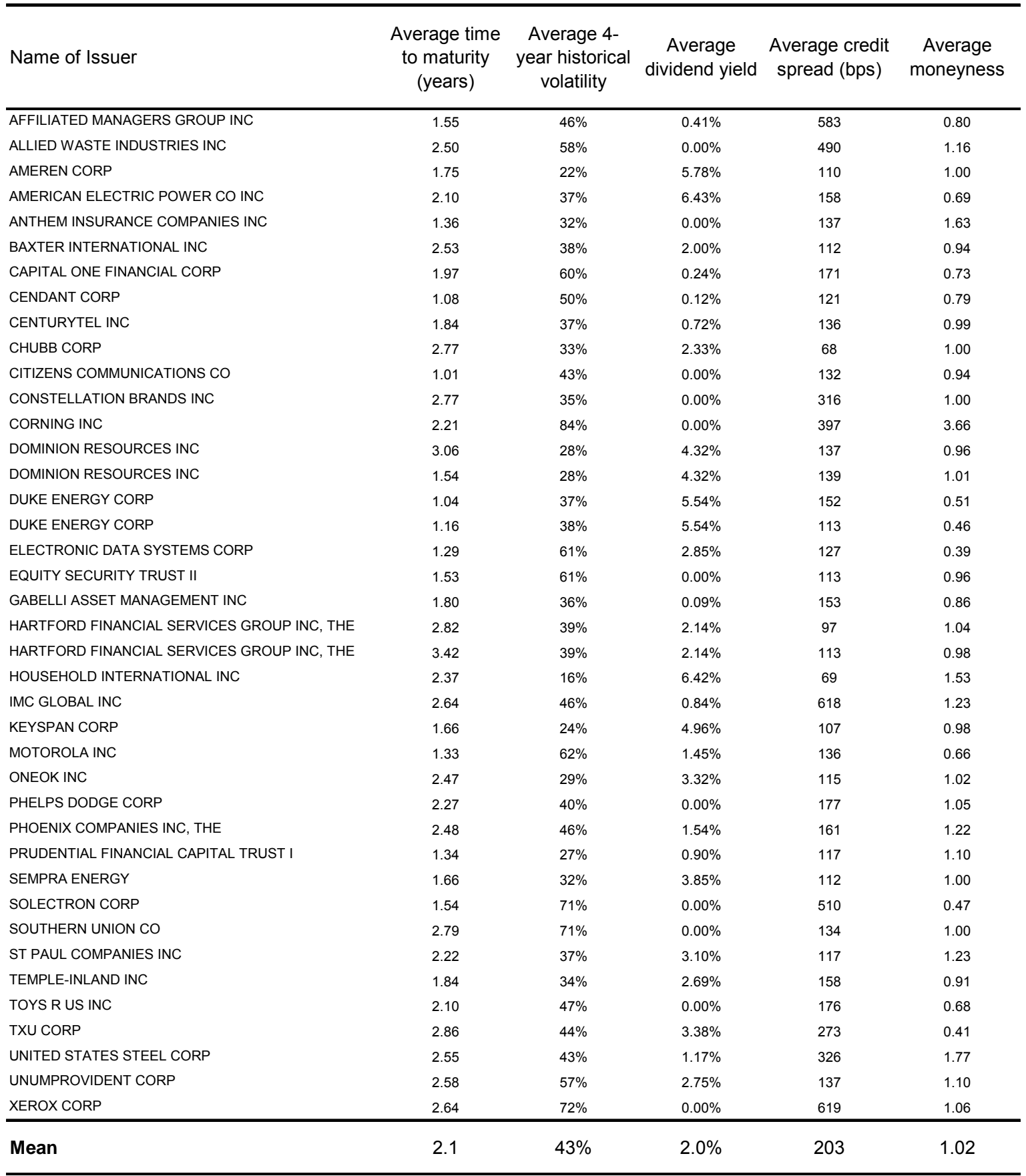

This exhibit provides some characteristics of our sample within the observed time window. The average time to maturity indicates where the securities are within their life cycle. The average 4-year historical volatility describes the standard deviation of the continuously compounded returns of the underlying shares. The average dividend yield describes the average dividend divided by current stock price. Moody's median bond spread data gives the credit spreads. The moneyness is defined as following: moneyness $=1$, i.e., the current stock price is between the lower and the upper strike price; moneyness $<$ 1, i.e., the current stock price is below the lower strike price; moneyness $>1$, i.e., the current stock price is above the upper strike price. 
Exhibit 4

Pricing overview

\begin{tabular}{|c|c|c|c|c|c|}
\hline Name of Mandatory Convertible Bond & Data Points & $\begin{array}{c}\text { Mean percentage } \\
\text { error } \\
\left(E_{l}\right) \\
\end{array}$ & $\begin{array}{l}\text { Root mean } \\
\text { squared error } \\
\left(R M S E_{l}\right)\end{array}$ & $\begin{array}{c}\text { Mean } \\
\text { absolute } \\
\text { error } \\
\left(M A E_{l}\right)\end{array}$ & $\left(\sigma_{E, I}\right)$ \\
\hline AFFILIATED MANAGERS GROUP INC $17.11 .20046 \%$ & 498 & $-0.53 \%$ * & $2.16 \%$ & $1.70 \%$ & $2.10 \%$ \\
\hline ALLIED WASTE INDUSTRIES INC 01.04.2006 6.25\% & 274 & $-2.01 \% *$ & $3.07 \%$ & $2.37 \%$ & $2.32 \%$ \\
\hline AMEREN CORP $15.05 .20059 .75 \%$ & 345 & $1.28 \%$ * & $3.22 \%$ & $2.59 \%$ & $2.96 \%$ \\
\hline AMERICAN ELECTRIC POWER CO INC $16.08 .20059 .25 \%$ & 394 & $8.48 \%$ * & $9.52 \%$ & $8.50 \%$ & $4.32 \%$ \\
\hline ANTHEM INSURANCE COMPANIES INC $15.11 .20046 \%$ & 403 & $-0.43 \%$ * & $1.05 \%$ & $0.77 \%$ & $0.96 \%$ \\
\hline BAXTER INTERNATIONAL INC 16.02 .2006 7\% & 351 & $1.86 \%$ * & $3.11 \%$ & $2.81 \%$ & $2.50 \%$ \\
\hline CAPITAL ONE FINANCIAL CORP $17.05 .20056 .25 \%$ & 456 & $-0.74 \%$ * & $2.21 \%$ & $1.58 \%$ & $2.09 \%$ \\
\hline CENDANT CORP $17.08 .2004 \quad 7.75 \%$ & 389 & $5.51 \%$ * & $5.87 \%$ & $5.51 \%$ & $2.01 \%$ \\
\hline CENTURYTEL INC $15.05 .20056 .875 \%$ & 394 & $-1.90 \%$ * & $2.63 \%$ & $2.31 \%$ & $1.83 \%$ \\
\hline CHUBB CORP $16.08 .20067 \%$ & 220 & $-0.98 \% *$ & $1.40 \%$ & $1.13 \%$ & $1.01 \%$ \\
\hline CITIZENS COMMUNICATIONS CO 17.08 .2004 6.75\% & 353 & $-0.03 \%$ & $2.84 \%$ & $2.43 \%$ & $2.84 \%$ \\
\hline CONSTELLATION BRANDS INC 01.09.2006 5.75\% & 194 & $2.73 \%$ * & $3.75 \%$ & $3.36 \%$ & $2.58 \%$ \\
\hline CORNING INC $16.08 .20057 \%$ & 450 & $-0.95 \% *$ & $1.86 \%$ & $1.39 \%$ & $1.60 \%$ \\
\hline DOMINION RESOURCES INC 15.05 .2006 8.75\% & 498 & $0.16 \%$ & $4.37 \%$ & $3.65 \%$ & $4.37 \%$ \\
\hline DOMINION RESOURCES INC $16.11 .20049 .5 \%$ & 498 & $-1.28 \%$ * & $1.91 \%$ & $1.41 \%$ & $1.42 \%$ \\
\hline DUKE ENERGY CORP $18.05 .20048 .25 \%$ & 498 & $7.76 \%$ * & $11.37 \%$ & $8.16 \%$ & $8.31 \%$ \\
\hline DUKE ENERGY CORP $16.11 .20048 \%$ & 300 & $8.14 \%$ * & $9.48 \%$ & $8.20 \%$ & $4.86 \%$ \\
\hline ELECTRONIC DATA SYSTEMS CORP 17.08 .2004 7.625\% & 498 & $1.03 \%$ * & $2.50 \%$ & $1.86 \%$ & $2.28 \%$ \\
\hline EQUITY SECURITY TRUST II $15.01 .20056 .25 \%$ & 405 & $-2.97 \%$ * & $3.30 \%$ & $2.99 \%$ & $1.44 \%$ \\
\hline GABELLI ASSET MANAGEMENT INC $17.02 .20056 .95 \%$ & 498 & $-3.90 \% *$ & $5.86 \%$ & $5.08 \%$ & $4.38 \%$ \\
\hline HARTFORD FINANCIAL SERVICES GROUP INC, THE 16.08 .2006 7\% & 241 & $-2.33 \% *$ & $2.46 \%$ & $2.34 \%$ & $0.78 \%$ \\
\hline HARTFORD FINANCIAL SERVICES GROUP INC, THE 16.11 .2006 6\% & 421 & $-2.06 \%$ * & $2.29 \%$ & $2.10 \%$ & $1.00 \%$ \\
\hline HOUSEHOLD INTERNATIONAL INC $15.02 .20068 .875 \%$ & 272 & $-1.03 \%$ * & $1.84 \%$ & $1.50 \%$ & $1.52 \%$ \\
\hline IMC GLOBAL INC 01.07.2006 7.5\% & 216 & $-2.42 \%$ * & $3.37 \%$ & $2.61 \%$ & $2.36 \%$ \\
\hline KEYSPAN CORP $16.05 .20058 .75 \%$ & 300 & $2.62 \%$ * & $3.04 \%$ & $2.67 \%$ & $1.55 \%$ \\
\hline MOTOROLA INC 16.11 .2004 7\% & 388 & $5.81 \%$ * & $6.38 \%$ & $5.82 \%$ & $2.65 \%$ \\
\hline ONEOK INC $16.02 .20068 .5 \%$ & 323 & $-2.66 \% *$ & $3.05 \%$ & $2.72 \%$ & $1.48 \%$ \\
\hline PHELPS DODGE CORP $15.08 .20056 .75 \%$ & 484 & $-3.23 \%$ * & $3.75 \%$ & $3.46 \%$ & $1.92 \%$ \\
\hline PHOENIX COMPANIES INC, THE $16.02 .20067 .25 \%$ & 328 & $-3.04 \% *$ & $3.62 \%$ & $3.14 \%$ & $1.96 \%$ \\
\hline PRUDENTIAL FINANCIAL CAPITAL TRUST I $15.11 .20046 .75 \%$ & 394 & $-1.05 \% *$ & $1.87 \%$ & $1.57 \%$ & $1.54 \%$ \\
\hline SEMPRA ENERGY $17.05 .20058 .5 \%$ & 299 & $-1.94 \% *$ & $2.23 \%$ & $1.94 \%$ & $1.11 \%$ \\
\hline SOLECTRON CORP $15.11 .2004 \quad 7.25 \%$ & 498 & $0.04 \%$ & $3.14 \%$ & $2.60 \%$ & $3.15 \%$ \\
\hline SOUTHERN UNION CO $16.08 .20065 .75 \%$ & 229 & $1.08 \%$ * & $1.70 \%$ & $1.54 \%$ & $1.31 \%$ \\
\hline ST PAUL COMPANIES INC 16.08.2005 9\% & 454 & $-2.57 \%$ * & $2.85 \%$ & $2.58 \%$ & $1.24 \%$ \\
\hline TEMPLE-INLAND INC 17.05.2005 7.5\% & 393 & $0.79 \%$ * & $1.81 \%$ & $1.52 \%$ & $1.63 \%$ \\
\hline TOYS R US INC $16.08 .20056 .25 \%$ & 394 & $0.76 \%$ * & $2.59 \%$ & $2.12 \%$ & $2.48 \%$ \\
\hline TXU CORP 16.05.2006 8.125\% & 394 & $6.51 \%$ * & $8.70 \%$ & $7.48 \%$ & $5.77 \%$ \\
\hline UNITED STATES STEEL CORP 15.06 .2006 7\% & 195 & $-2.18 \% *$ & $2.80 \%$ & $2.35 \%$ & $1.75 \%$ \\
\hline UNUMPROVIDENT CORP 15.05 .2006 8.25\% & 254 & $-2.29 \% *$ & $2.62 \%$ & $2.37 \%$ & $1.27 \%$ \\
\hline XEROX CORP $01.07 .2006 \quad 6.25 \%$ & 219 & $-1.28 \%{ }^{*}$ & $1.67 \%$ & $1.38 \%$ & $1.08 \%$ \\
\hline Mean over all Mandatory Convertibles (40 Bonds) & 14,612 & $0.27 \%$ * & $3.58 \%$ & $3.04 \%$ & $2.34 \%$ \\
\hline Mean over all Data Points (14'612 Data Points) & 14,612 & $0.33 \%$ * & $4.50 \%$ & $3.10 \%$ & $4.45 \%$ \\
\hline
\end{tabular}

Data Points $\left(N_{l}\right)$ indicates the number of days for which model prices are computed. * denotes significance level of $1 \%$ for rejection of the null hypothesis that model and market prices are equal in the mean. The root mean squared error (RMSE) for each security $l$ is defined as $\operatorname{RMSE}_{l}=\left(1 / N_{l} \cdot \sum_{t=1}^{N_{l}}\left(E_{l, t}\right)^{2}\right)^{1 / 2}$. The mean absolute error (MAE) for security $l$ is defined as $\mathrm{MAE}_{l}=1 / N_{l} \cdot \sum_{l=1}^{N_{l}}\left|E_{l, l}\right|$. Std. Dev. denotes the standard deviation of the pricing errors. 


\section{Exhibit 5}

Distribution of pricing errors

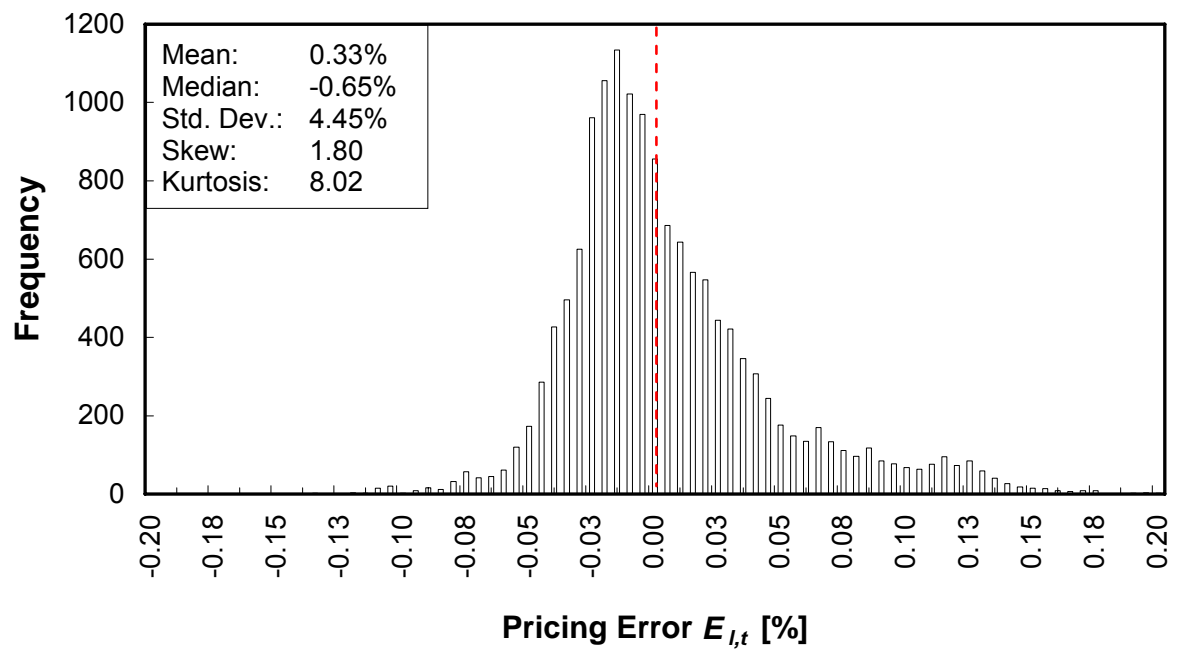

Distribution of pricing errors for 14,612 data points of the whole sample. The distribution is right-skewed with a skew of 1.80 and leptokurtic with a kurtosis of 8.02 .

\section{Exhibit 6}

Robustness of the model with respect to volatility

\begin{tabular}{lllllll}
\hline $\begin{array}{l}\text { Volatility window } \\
\text { (years) }\end{array}$ & $\mathbf{0 . 2 5}$ & $\mathbf{1}$ & $\mathbf{2}$ & $\mathbf{3}$ & $\mathbf{4}$ & $\mathbf{5}$ \\
\hline Mean Pricing Error & $0.22 \%{ }^{*}$ & $0.49 \%{ }^{*}$ & $0.43 \%{ }^{*}$ & $0.36 \%{ }^{*}$ & $0.33 \%{ }^{*}$ & $0.28 \%{ }^{*}$ \\
\hline Std. Dev. & $4.28 \%$ & $4.46 \%$ & $4.56 \%$ & $4.47 \%$ & $4.45 \%$ & $4.43 \%$ \\
Median & $-0.45 \%$ & $-0.43 \%$ & $-0.64 \%$ & $-0.63 \%$ & $-0.65 \%$ & $-0.63 \%$ \\
Skewness & 2.01 & 1.94 & 1.89 & 1.84 & 1.80 & 1.79 \\
Kurtosis & 9.97 & 8.56 & 7.66 & 8.01 & 8.02 & 8.11 \\
\hline
\end{tabular}

This exhibit shows pricing statistics for different rolling window lengths used for volatility estimation. As can be seen, the estimation window has a very limited impact on pricing errors.

$*$ denotes significance level of $1 \%$. Std. Dev. denotes the standard deviation of the pricing errors. 


\section{Exhibit 7}

Pricing error for different moneyness classes

\begin{tabular}{lllll}
\hline Moneyness, $M_{l, t}$ & Mean pricing error & RMSE & Std. Dev. & Data Points \\
\hline deep out of the money $(0-0.49)$ & $4.25 \%$ * & $8.10 \%$ & $6.90 \%$ & 1712 \\
out of the money $(0.50-0.99)$ & $1.22 \%$ * & $4.89 \%$ & $4.74 \%$ & 4994 \\
at the money $(1.00)$ & $-0.61 \%$ * & $3.00 \%$ & $2.94 \%$ & 4199 \\
in the money $(1.01-1.50)$ & $-1.90 \%$ * & $2.51 \%$ & $1.64 \%$ & 2615 \\
deep in the money $(>1.50)$ & $-0.87 \%$ * & $2.07 \%$ & $1.87 \%$ & 1092 \\
\hline
\end{tabular}

Mean Pricing Error states the extent to which market prices are, on average, above model prices for a given moneyness class. $*$ denotes significance level of $1 \%$. RMSE is the root mean squared error of the observations in the respective class. Std. Dev. is the standard deviation of the observations in the respective class. Data Points is the number of records in the category.

\section{Exhibit 8}

Pricing error with respect to moneyness

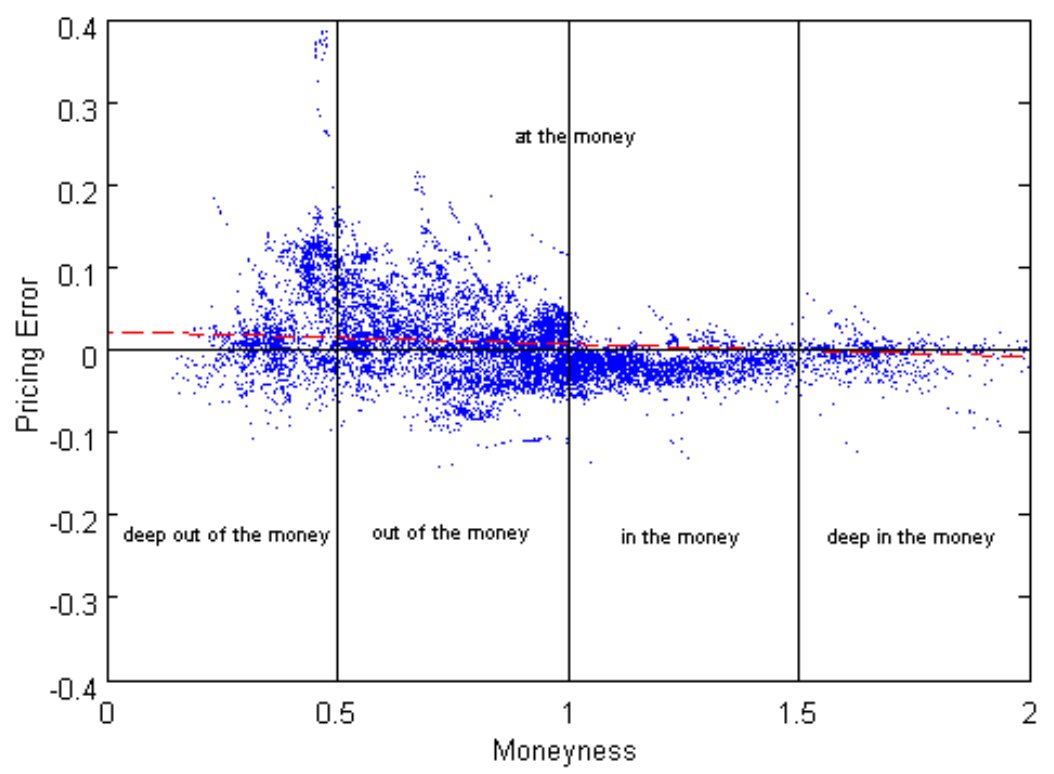

This exhibit shows the percentage pricing error of each daily observed market price with respect to the moneyness of the mandatory convertible. Assuming a linear dependence (the dashed line represent a linear trend), the pricing error decreases with the moneyness. 


\section{Exhibit 9}

Regression analysis of factors influencing pricing errors

\begin{tabular}{|c|c|c|c|c|c|c|c|c|}
\hline Reg \# & $\begin{array}{c}\text { CONSTANT } \\
\alpha_{0} \\
\end{array}$ & $\begin{array}{c}\text { DIVIDEND YIELD } \\
\alpha_{1} \\
\end{array}$ & $\begin{array}{c}\text { COUPON } \\
\alpha_{2} \\
\end{array}$ & $\begin{array}{c}\text { MONEYNESS } \\
\alpha_{3} \\
\end{array}$ & $\begin{array}{c}\text { MATURITY } \\
\alpha_{4} \\
\end{array}$ & $\begin{array}{c}\text { CREDITSPREAD } \\
\alpha_{5} \\
\end{array}$ & $\begin{array}{c}\text { VOLATILITY } \\
\alpha_{6} \\
\end{array}$ & $A d j . R^{2}$ \\
\hline (1) & $\begin{array}{c}-0.011 \\
(-7.76) \text { * }\end{array}$ & $\begin{array}{c}0.706 \\
(10.42) *\end{array}$ & & & & & & $11.24 \%$ \\
\hline (2) & $\begin{array}{l}-0.061 \\
(-8.18) \text { * }\end{array}$ & & $\begin{array}{l}\mathbf{0 . 8 7 1} \\
(8.04) \text { * }\end{array}$ & & & & & $4.57 \%$ \\
\hline (3) & $\begin{array}{l}0.017 \\
(5.90) \text { * }\end{array}$ & & & $\begin{array}{l}-0.014 \\
(-5.83) \text { * }\end{array}$ & & & & $4.26 \%$ \\
\hline (4) & $\begin{array}{l}0.038 \\
(9.99) \text { * }\end{array}$ & & & & $\begin{array}{c}-0.017 \\
(-10.55) \text { * }\end{array}$ & & & $8.85 \%$ \\
\hline (5) & $\begin{array}{l}0.010 \\
(5.58) \text { * }\end{array}$ & & & & & $\begin{array}{l}-0.352 \\
(-7.31) \text { * }\end{array}$ & & $1.44 \%$ \\
\hline (6) & $\begin{array}{l}\mathbf{0 . 0 0 4} \\
(1.55)\end{array}$ & & & & & & $\begin{array}{l}-0.003 \\
(-0.48)\end{array}$ & $0.00 \%$ \\
\hline (7) & $\begin{array}{l}0.048 \\
(9.20) \text { * }\end{array}$ & & & $\begin{array}{l}-0.014 \\
(-6.73) \text { * }\end{array}$ & $\begin{array}{c}-0.017 \\
(-10.72) \text { * }\end{array}$ & & $\begin{array}{l}\mathbf{0 . 0 0 7} \\
(1.35)\end{array}$ & $12.95 \%$ \\
\hline (8) & $\begin{array}{c}0.053 \\
(11.40) \text { * }\end{array}$ & & & $\begin{array}{l}-0.013 \\
(-6.20) \text { * }\end{array}$ & $\begin{array}{c}-0.016 \\
(-10.42) \text { * }\end{array}$ & $\begin{array}{l}-0.173 \\
(-3.86) \text { * }\end{array}$ & & $13.22 \%$ \\
\hline (9) & $\begin{array}{l}-0.007 \\
(-0.84)\end{array}$ & & $\begin{array}{l}\mathbf{0 . 7 4 6} \\
(7.23) \text { * }\end{array}$ & $\begin{array}{l}-0.013 \\
(-6.10) \text { * }\end{array}$ & $\begin{array}{c}-0.016 \\
(-10.51)\end{array}$ & & & $16.21 \%$ \\
\hline (10) & $\begin{array}{l}0.035 \\
(9.16) \text { * }\end{array}$ & $\begin{array}{c}0.672 \\
(10.73) \text { * }\end{array}$ & & $\begin{array}{l}-0.009 \\
(-5.00) \text { * }\end{array}$ & $\begin{array}{c}-0.018 \\
(-11.36) \text { * }\end{array}$ & & & $22.64 \%$ \\
\hline
\end{tabular}

Pricing errors $(E)$ are regressed against the mandatory convertible's dividend yield in $\%(q)$, the annual coupon in $\%(I)$, the moneyness $(M)$, the maturity $\Delta T$ (in years), the credit spread in $\%(c S)$ and the historical four-year volatility $(\sigma): E_{l, t}=\alpha_{0}+\alpha_{1} q_{l, t}+\alpha_{2} I_{l}+\alpha_{3} M_{l, t}+\alpha_{4} \Delta T_{l, t}+\alpha_{5} c s_{l, t}+\alpha_{6} \sigma_{l, t}+\varepsilon_{l, t} \cdot$ t-values are given in parentheses. Standard errors are adjusted for autocorrelation and heteroskedasticity according to Newey and West [1987]. Adj. $R^{2}$ denotes the value of the adjusted $R^{2}$ (coefficient of determination). In regression (1) to (6), each regressor is estimated separately. In regression (7) to (10), we omit the highly correlated regressors. * denotes significance level of $1 \%$. Numbers in parentheses are t-values. 


\section{Exhibit 10}

Hedging performance: hedge against the market with a rebalancing period of one trading day

\begin{tabular}{|c|c|c|c|c|c|}
\hline Name of Mandatory Convertible Bond & $\begin{array}{l}\text { Data Points } \\
\qquad\left(N_{I)}\right.\end{array}$ & $\begin{array}{r}\text { Mean } \\
\text { percentage } \\
\text { hedging } \\
\text { error } \\
\left(M P H E_{I}\right) \\
\end{array}$ & $\begin{array}{c}\text { Root mean } \\
\text { squared error } \\
\left(R M S E_{l}\right)\end{array}$ & $\begin{array}{c}\text { Mean } \\
\text { absolute } \\
\text { error } \\
\left(M A E_{l}\right) \\
\end{array}$ & $\left(\sigma_{l}\right)$ \\
\hline AFFILIATED MANAGERS GROUP INC $17.11 .20046 \%$ & 497 & $-0.02 \%$ & $0.98 \%$ & $0.67 \%$ & $0.98 \%$ \\
\hline ALLIED WASTE INDUSTRIES INC $01.04 .20066 .25 \%$ & 273 & $-0.03 \%$ & $1.38 \%$ & $1.00 \%$ & $1.38 \%$ \\
\hline AMEREN CORP $15.05 .20059 .75 \%$ & 344 & $-0.01 \%$ & $1.30 \%$ & $0.59 \%$ & $1.31 \%$ \\
\hline AMERICAN ELECTRIC POWER CO INC $\quad \begin{array}{l}16.08 .2005 \\
9.25 \%\end{array}$ & 393 & $0.02 \%$ & $1.23 \%$ & $0.82 \%$ & $1.23 \%$ \\
\hline ANTHEM INSURANCE COMPANIES INC $15.11 .20046 \%$ & 402 & $-0.01 \%$ & $0.71 \%$ & $0.52 \%$ & $0.71 \%$ \\
\hline BAXTER INTERNATIONAL INC $16.02 .20067 \%$ & 350 & $0.00 \%$ & $0.93 \%$ & $0.66 \%$ & $0.93 \%$ \\
\hline CAPITAL ONE FINANCIAL CORP $17.05 .20056 .25 \%$ & 455 & $-0.03 \%$ & $1.23 \%$ & $0.89 \%$ & $1.23 \%$ \\
\hline CENDANT CORP $17.08 .2004 \quad 7.75 \%$ & 388 & $-0.04 \%$ & $0.76 \%$ & $0.53 \%$ & $0.76 \%$ \\
\hline CENTURYTEL INC $15.05 .20056 .875 \%$ & 393 & $-0.01 \%$ & $1.00 \%$ & $0.72 \%$ & $1.01 \%$ \\
\hline CHUBB CORP $16.08 .20067 \%$ & 219 & $0.01 \%$ & $0.76 \%$ & $0.56 \%$ & $0.76 \%$ \\
\hline CITIZENS COMMUNICATIONS CO $17.08 .20046 .75 \%$ & 352 & $-0.01 \%$ & $1.17 \%$ & $0.71 \%$ & $1.18 \%$ \\
\hline CONSTELLATION BRANDS INC $01.09 .20065 .75 \%$ & 193 & $0.03 \%$ & $0.95 \%$ & $0.61 \%$ & $0.95 \%$ \\
\hline CORNING INC $16.08 .20057 \%$ & 449 & $-0.02 \%$ & $2.06 \%$ & $1.43 \%$ & $2.06 \%$ \\
\hline DOMINION RESOURCES INC 15.05 .2006 8.75\% & 497 & $0.00 \%$ & $1.19 \%$ & $0.51 \%$ & $1.19 \%$ \\
\hline DOMINION RESOURCES INC $16.11 .20049 .5 \%$ & 497 & $-0.02 \%$ & $1.16 \%$ & $0.59 \%$ & $1.16 \%$ \\
\hline DUKE ENERGY CORP $\quad 18.05 .2004 \quad 8.25 \%$ & 497 & $-0.08 \%$ & $2.34 \%$ & $1.01 \%$ & $2.34 \%$ \\
\hline DUKE ENERGY CORP $16.11 .20048 \%$ & 299 & $-0.03 \%$ & $0.96 \%$ & $0.65 \%$ & $0.97 \%$ \\
\hline ELECTRONIC DATA SYSTEMS CORP $17.08 .2004 \quad 7.625 \%$ & 497 & $-0.06 \%$ & $1.42 \%$ & $0.87 \%$ & $1.42 \%$ \\
\hline EQUITY SECURITY TRUST II $15.01 .20056 .25 \%$ & 404 & $-0.02 \%$ & $1.16 \%$ & $0.86 \%$ & $1.16 \%$ \\
\hline GABELLI ASSET MANAGEMENT INC $17.02 .20056 .95 \%$ & 497 & $0.00 \%$ & $1.14 \%$ & $0.78 \%$ & $1.14 \%$ \\
\hline HARTFORD FINANCIAL SERVICES GROUP INC, THE $16.08 .20067 \%$ & 240 & $0.00 \%$ & $0.68 \%$ & $0.49 \%$ & $0.68 \%$ \\
\hline HARTFORD FINANCIAL SERVICES GROUP INC, THE $16.11 .20066 \%$ & 420 & $-0.01 \%$ & $0.72 \%$ & $0.54 \%$ & $0.72 \%$ \\
\hline HOUSEHOLD INTERNATIONAL INC $15.02 .20068 .875 \%$ & 271 & $0.03 \%$ & $0.86 \%$ & $0.61 \%$ & $0.86 \%$ \\
\hline IMC GLOBAL INC $01.07 .2006 \quad 7.5 \%$ & 215 & $-0.01 \%$ & $1.76 \%$ & $1.30 \%$ & $1.76 \%$ \\
\hline KEYSPAN CORP $16.05 .20058 .75 \%$ & 299 & $0.00 \%$ & $0.59 \%$ & $0.39 \%$ & $0.59 \%$ \\
\hline MOTOROLA INC $16.11 .20047 \%$ & 387 & $-0.03 \%$ & $1.20 \%$ & $0.84 \%$ & $1.20 \%$ \\
\hline ONEOK INC $16.02 .20068 .5 \%$ & 322 & $0.01 \%$ & $0.70 \%$ & $0.52 \%$ & $0.71 \%$ \\
\hline PHELPS DODGE CORP $15.08 .20056 .75 \%$ & 483 & $-0.02 \%$ & $1.27 \%$ & $0.84 \%$ & $1.27 \%$ \\
\hline PHOENIX COMPANIES INC, THE $16.02 .2006 \quad 7.25 \%$ & 327 & $-0.01 \%$ & $1.23 \%$ & $0.89 \%$ & $1.23 \%$ \\
\hline PRUDENTIAL FINANCIAL CAPITAL TRUST I 15.11 .2004 6.75\% & 393 & $-0.02 \%$ & $0.86 \%$ & $0.61 \%$ & $0.86 \%$ \\
\hline SEMPRA ENERGY $17.05 .2005 \quad 8.5 \%$ & 298 & $-0.01 \%$ & $0.66 \%$ & $0.46 \%$ & $0.66 \%$ \\
\hline SOLECTRON CORP $15.11 .2004 \quad 7.25 \%$ & 497 & $-0.05 \%$ & $1.97 \%$ & $1.33 \%$ & $1.97 \%$ \\
\hline SOUTHERN UNION CO $16.08 .20065 .75 \%$ & 228 & $-0.01 \%$ & $0.82 \%$ & $0.61 \%$ & $0.83 \%$ \\
\hline ST PAUL COMPANIES INC $16.08 .20059 \%$ & 453 & $-0.01 \%$ & $0.98 \%$ & $0.73 \%$ & $0.99 \%$ \\
\hline TEMPLE-INLAND INC $17.05 .2005 \quad 7.5 \%$ & 392 & $-0.02 \%$ & $0.94 \%$ & $0.64 \%$ & $0.94 \%$ \\
\hline TOYS R US INC $16.08 .20056 .25 \%$ & 393 & $-0.03 \%$ & $1.36 \%$ & $0.92 \%$ & $1.36 \%$ \\
\hline TXU CORP $16.05 .20068 .125 \%$ & 393 & $0.01 \%$ & $1.06 \%$ & $0.66 \%$ & $1.06 \%$ \\
\hline UNITED STATES STEEL CORP 15.06 .2006 7\% & 194 & $-0.03 \%$ & $1.62 \%$ & $1.12 \%$ & $1.62 \%$ \\
\hline UNUMPROVIDENT CORP $15.05 .20068 .25 \%$ & 253 & $0.00 \%$ & $1.50 \%$ & $1.17 \%$ & $1.50 \%$ \\
\hline XEROX CORP $01.07 .2006 \quad 6.25 \%$ & 218 & $-0.01 \%$ & $1.13 \%$ & $0.87 \%$ & $1.13 \%$ \\
\hline Mean over all Mandatory Convertibles (40 Bonds) & 14,572 & $-0.01 \%$ & $1.14 \%$ & $0.76 \%$ & $1.14 \%$ \\
\hline Mean over all Data Points (14,572 Data Points) & 14,572 & $-0.02 \%$ & $1.24 \%$ & $0.77 \%$ & $1.24 \%$ \\
\hline
\end{tabular}

The hedging errors in percent are defined as $\hat{\varepsilon}_{t}^{\text {marter }} \approx\left(\Delta V_{t}^{\text {marter }}-\Delta H_{t}\right) / V_{t}^{\text {marter }}$. Data Points $\left(N_{l}\right)$ indicates the number of days for which prices are available. The mean percentage hedging error (MPHE) for each security $l$ is defined as $\mathrm{MPHE}_{l}=1 / N_{l} \cdot \sum_{l=1}^{N_{N}} \hat{\varepsilon}_{l t}^{\text {marker }}$. All values for the mean percentage hedging error are not significantly different from zero. The root mean squared error (RMSE) for each security $l$ is defined as $\operatorname{RMSE}_{l}=\left(1 / N_{l} \cdot \sum_{l=1}^{N_{l}}\left(\hat{\varepsilon}_{l l}^{\text {markel }}\right)^{2}\right)^{1 / 2}$. The mean absolute error (MAE) for security $l$ is defined as $\operatorname{MAE}_{l}=1 / N_{l} \cdot \sum_{t=1}^{N_{l}}\left|\hat{\varepsilon}_{t i}^{\text {market }}\right|$. Std. Dev. denotes the standard deviation of the hedging errors. 


\section{Exhibit 11}

Hedging performance: hedge against the model with a rebalancing period of one trading day

\begin{tabular}{|c|c|c|c|c|c|}
\hline & $\begin{array}{l}\text { Data Points } \\
\qquad\left(N_{l)}\right.\end{array}$ & $\begin{array}{r}\text { Mean } \\
\text { percentage } \\
\text { hedging } \\
\text { error } \\
\left(M P H E_{l}\right) \\
\end{array}$ & $\begin{array}{c}\begin{array}{c}\text { Root mean } \\
\text { squared error }\end{array} \\
\left(R M S E_{l}\right)\end{array}$ & $\begin{array}{c}\text { Mean } \\
\text { absolute } \\
\text { error } \\
\left(M A E_{l}\right)\end{array}$ & $\begin{array}{c}\text { Std. Dev. } \\
\left(\sigma_{l}\right)\end{array}$ \\
\hline Mean over all Mandatory Convertibles (40 Bonds) & 14,572 & $-0.01 \%$ & $0.27 \%$ & $0.07 \%$ & $0.27 \%$ \\
\hline Mean over all Data Points (14,572 Data Points) & 14,572 & $-0.02 \%$ * & $0.33 \%$ & $0.08 \%$ & $0.33 \%$ \\
\hline
\end{tabular}

The hedging errors in percent are defined as $\hat{\varepsilon}_{t}^{\text {model }} \approx\left(\Delta V_{t}^{\text {model }}-\Delta H_{t}\right) / V_{t}^{\text {model }}$. Data Points $\left(N_{l}\right)$ indicates the number of days for which prices are available. The mean percentage hedging error (MPHE) for each security $l$ is defined as $\mathrm{MPHE}_{l}=1 / N_{l} \cdot \sum_{t=1}^{N_{h}} \hat{\varepsilon}_{l}^{\text {model }} \cdot{ }^{*}$ denotes significance level of $1 \%$ for rejection of the null hypothesis that the mean percentage hedging errors are zero in the mean. The root mean squared error (RMSE) for each security $l$ is defined as $\operatorname{RMSE}_{l}=\left(1 / N_{l} \cdot \sum_{t=1}^{N_{I}}\left(\hat{\varepsilon}_{l}^{\text {model }}\right)^{2}\right)^{1 / 2}$. The mean absolute error (MAE) for security $l$ is defined as $M A E_{l}=1 / N_{l} \cdot \sum_{t=1}^{N_{l}}\left|\hat{\varepsilon}_{t h}^{m o d e l}\right|$. Std. Dev. denotes the standard deviation of the hedging errors. 


\section{Exhibit 12}

Analysis of the hedging errors: hedge against the market with a rebalancing period of one trading day

\begin{tabular}{|c|c|c|c|}
\hline Dividend Yield (\%) & $\begin{array}{c}\text { Mean Percentage } \\
\text { Hedging Error (MPHE) } \\
\end{array}$ & Std. Dev. & Datapoints \\
\hline $0.00-0.49$ & $-0.02 \%$ & $1.31 \%$ & 5609 \\
\hline $0.50-1.99$ & $-0.01 \%$ & $1.14 \%$ & 2671 \\
\hline $2.00-3.24$ & $-0.01 \%$ & $0.99 \%$ & 2318 \\
\hline $3.25-5.49$ & $-0.02 \%$ & $1.08 \%$ & 3002 \\
\hline$\geq 5.50$ & $-0.03 \%$ & $1.83 \%$ & 1007 \\
\hline \multicolumn{4}{|l|}{ Coupon } \\
\hline$\leq 6.99 \%$ & $-0.01 \%$ & $1.08 \%$ & 5615 \\
\hline $7.00 \%-7.99 \%$ & $-0.03 \%$ & $1.40 \%$ & 4166 \\
\hline$\geq 8.00 \%$ & $-0.01 \%$ & $1.25 \%$ & 4828 \\
\hline \multicolumn{4}{|l|}{ Moneyness } \\
\hline deep out of the money $(0-0.49)$ & $-0.07 \%$ & $1.80 \%$ & 1711 \\
\hline out of the money $(0.50-0.99)$ & $0.00 \%$ & $1.15 \%$ & 4993 \\
\hline at the money $(1.00)$ & $-0.01 \%$ & $1.01 \%$ & 4198 \\
\hline in the money $(1.01-1.50)$ & $-0.02 \%$ & $1.13 \%$ & 2614 \\
\hline deep in the money $(>1.50)$ & $-0.03 \%$ & $1.52 \%$ & 1091 \\
\hline \multicolumn{4}{|l|}{ Maturity (Years) } \\
\hline $0.00-0.99$ & $-0.03 \%$ & $1.52 \%$ & 1629 \\
\hline $1.00-1.49$ & $-0.02 \%$ & $1.11 \%$ & 2525 \\
\hline $1.50-1.99$ & $-0.02 \%$ & $1.14 \%$ & 3054 \\
\hline $2.00-2.49$ & $0.00 \%$ & $1.25 \%$ & 3348 \\
\hline$>2.50$ & $-0.01 \%$ & $1.25 \%$ & 4051 \\
\hline \multicolumn{4}{|l|}{ Credit Spread (bps) } \\
\hline $0-129$ & $-0.02 \%$ & $1.11 \%$ & 6530 \\
\hline $130-159$ & $-0.01 \%$ & $1.03 \%$ & 2442 \\
\hline $160-299$ & $-0.01 \%$ & $1.31 \%$ & 3163 \\
\hline$>300$ & $-0.02 \%$ & $1.59 \%$ & 2473 \\
\hline
\end{tabular}

The hedging errors in percent are defined as $\hat{\varepsilon}_{t}^{\text {market }} \approx\left(\Delta V_{t}^{\text {market }}-\Delta H_{t}\right) / V_{t}^{\text {market }}$. Data Points $\left(N_{l}\right)$ indicates the number of days for which prices are available. The mean percentage hedging error (MPHE) for each security $l$ is defined as $M P H E_{l}=1 / N_{l} \cdot \sum_{t=1}^{N_{l}} \hat{\varepsilon}_{l}^{\text {market }}$. Std. Dev. denotes the standard deviation of the hedging errors. All mean percentage hedging errors are not significantly different from zero. 


\section{Exhibit 13}

Hedging overview: hedge against the market and model with a rebalancing period of 5 trading days

\begin{tabular}{|c|c|c|c|c|}
\hline Data Points & $\begin{array}{r}\text { Mean } \\
\text { percentage } \\
\text { hedging } \\
\text { error }\end{array}$ & $\begin{array}{l}\text { Root mean } \\
\text { squared error }\end{array}$ & $\begin{array}{l}\text { Mean } \\
\text { absolute } \\
\text { error }\end{array}$ & Std. Dev. \\
\hline$\left(N_{l}\right)$ & $\left(M P H E_{l}\right)$ & $\left(R M S E_{l}\right)$ & $\left(M A E_{l}\right)$ & $\left(\sigma_{l}\right)$ \\
\hline
\end{tabular}

Hedge against the market

\begin{tabular}{lcccc}
\hline Mean over all Mandatory Convertibles (40 Bonds) & 2,930 & $-0.23 \%$ & $3.14 \%$ & $2.30 \%$ \\
\hline Mean over all Data Points (2,930 Data Points) & 2,930 & $-0.18 \% *$ & $3.57 \%$ & $2.37 \%$ \\
\hline
\end{tabular}

Hedge against the model

\begin{tabular}{|c|c|c|c|c|c|}
\hline Mean over all Mandatory Convertibles (40 Bonds) & 2,930 & $-0.21 \%$ & $3.08 \%$ & $2.25 \%$ & $3.08 \%$ \\
\hline Mean over all Data Points (2,930 Data Points) & 2,930 & $-0.17 \%$ * & $3.56 \%$ & $2.34 \%$ & $3.56 \%$ \\
\hline
\end{tabular}

The hedging errors in percent are defined as $\hat{\varepsilon}_{t}^{\text {market/model }} \approx\left(\Delta V_{t}^{\text {marketmodel }}-\Delta H_{t}\right) / V_{t}^{\text {marketmodel }}$ for the hedge against the market and the hedge against the model, respectively. Data Points $\left(N_{l}\right)$ indicates the number of days for which prices are available. $*$ denotes significance level of $1 \%$ for rejection of the null hypothesis that MPHE are zero. The mean percentage hedging error (MPHE) for each security $l$ is defined as $M P H E_{l}=1 / N_{l} \cdot \sum_{t=1}^{N_{l}} \hat{\varepsilon}_{l t}^{\text {marketmodel }}$. The root mean squared error (RMSE) for each security $l$ is defined as $\operatorname{RMSE}_{l}=\left(1 / N_{l} \cdot \sum_{t=1}^{N_{l}}\left(\hat{\varepsilon}_{t}^{\text {marketmodel }}\right)^{2}\right)^{1 / 2}$. The mean absolute error (MAE) for security $l$ is defined as $M A E_{l}=1 / N_{l} \cdot \sum_{t=1}^{N_{l}}\left|\hat{\varepsilon}^{\text {market/model }}\right|$. Std. Dev. denotes the standard deviation of the hedging errors. 


\section{Endnotes}

1 They also adjust for dilution in their valuation model. However, dilution in share prices should be considered when mandatory convertibles are issued only. Afterwards, the dilution in shares of the issuing company is already anticipated and the effects have already been accounted for in the current common stock price. Therefore, valuing mandatory convertibles after the primary issue does not require an adjustment for dilution.

${ }^{2}$ As an alternative to the simple component model used in this paper, a multi-dimensional lattice model within a framework such as the one proposed by Das and Sundaram [2004] could be used. Such a model would provide more flexibility and allows for modeling correlation between different risk factors. However, the choice of the component model, where the components are valued by a standard option pricing model, seems justified because of the simple structure of the mandatory convertible bonds analyzed in this study. For example, a credit model only affects the value of the stream of coupon payments, but not the basic mandatory structure itself. As a consequence, a correlation model for equity, interest rates, and credit spreads is likely to have a very limited price impact.

${ }^{3}$ Note that $V_{t}$ gives the dirty price of the mandatory convertible (i.e. including accrued interest) in monetary units, while during the exchange trade clean prices are quoted in general.

${ }^{4}$ In combination with the options, the par value determines the payoff that is settled by the delivery of stock at maturity. As the firm is always able to deliver its stock - perhaps worthless stock in case of bankruptcy to the holder of the security, the par value is essentially riskless.

${ }^{5}$ A hard call feature allows the issuer of a mandatory convertible to redeem the security before maturity. In only four issues provisional or soft call features exist. In that case the company can force conversion into common stock prior to maturity if the stock price is deeply in-the-money (e.g. $150 \%$ of the upper strike price) for a predefined period of consecutive trading days (e.g., 20 out of 30). This "qualifying period" introduces a path dependent feature not considered in the analysis. Because the bond price approaches the intrinsic value for securities deeply in-the-money, this option feature is expected to have a minor effect on prices and is neglected.

${ }^{6}$ See Equation (9) and Section 4 for a definition.

${ }^{7}$ See, for example, Ammann et. al [2005], who report a mean RMSE of $6.18 \%$ in their study of U.S. convertible bonds, and King [1986], who reports a standard deviation of more than $7.20 \%$ in his pricing study of U.S. convertible bonds.

${ }^{8}$ The pattern of the pricing error versus moneyness might perhaps also be explained by fat-tailed return distributions for the underlying stock. Model prices of the bonds are too low for (deep) out-of-the-money options and too high for (deep) in-the-money options in the presence of a symmetric option smile. An out-ofthe-money mandatory convertible bond contains a short put (out-of-the-money) and a long call (more deeply out-of-the-money). Therefore, the model underprices the bond because the underpricing of the call is greater than the underpricing of the put. Reversely, for an in-the-money mandatory convertible bond, the short put is more deeply in-the-money than the long call. Therefore, the model overprices the bond because the underpricing of the put is greater than the underpricing of the call. The observed (Exhibit 7) pattern of the pricing errors is consistent with this explanation.

${ }^{9}$ According to Newey West [1987] and current practice, the truncation lag is set to truncate[ $\left[4(K / 100)^{2 / 9}\right]=$ 12 with $K=14,612$ (number of data points).

${ }^{10}$ See Figlewski [2002] for an analysis of hedging performance.

${ }^{11}$ All parameters are defined as in Section 2.2. 
${ }^{12}$ The null hypothesis of identical RMSE cannot be rejected if tested according to Diebold and Mariano [1995]. 